\title{
The genus Eleocharis (Cyperaceae) in the restinga of Pará state, Brazil
}

\author{
Juliene de Fátima Maciel-Silva ${ }^{1,2}$, Clebiana de Sá Nunes ${ }^{2,3} \&$ André dos Santos Bragança Gil ${ }^{2,4}$
}

\begin{abstract}
This work reports eight Eleocharis species for the restinga of Pará state, Brazil: E. bahiensis, E. endounifascis, E. geniculata, E. interstincta, E. minima, E. mutata, E. sellowiana, and E. urceolata. Two species are new records for the state: E. bahiensis, and E. urceolata. An identification key, morphological descriptions, taxonomic comments, and illustrations of the species in the study area are provided.
\end{abstract}

Key words: Amazon, aquatic plants, Cyperoideae, sandy coast, taxonomy.

\section{Resumo}

Foram confirmadas oito espécies de Eleocharis para as restingas do estado do Pará, Brasil: E. bahiensis, E. endounifascis, E. geniculata, E. interstincta, E. minima, E. mutata, E. sellowiana e E. urceolata. Duas espécies são novos registros para o estado: E. bahiensis e E. urceolata. São apresentadas chave de identificação, descrições morfológicas, comentários taxonômicos e pranchas ilustrativas das espécies de Eleocharis ocorrentes na área de estudo.

Palavras-chave: Amazônia, plantas aquáticas, Cyperoideae, costa arenosa, taxonomia.

\section{Introduction}

Eleocharis R. Br. (Cyperaceae) comprises approximately 250 species distributed in tropical and subtropical regions of America (Goetghebeur 1998; González-Elizondo \& Tena-Flores 2000). In Brazil it is the third largest genus of Cyperaceae, being represented by 82 species (BFG 2015). The morphology of Eleocharis is simple, with distinct intergeneric characteristics, such as reduced leaves, a tubular sheath, absence of the typical involucral bracts found in Cyperaceae, and an inflorescence reduced to a single spikelet (González-Elizondo \& Peterson 1997). Identifying species of Eleocharis is often very difficult because of the small size of its diagnostic structures, such as glumes, achenes, and stylopodium (Svenson 1929; Faria 1998; Gil \& Bove 2004).

There are some taxonomic treatments for Eleocharis in Brazil (notably, Faria 1998; Gil 2004; Trevisan 2005, 2009), regional checklists (e.g., Gil \& Bove 2004, 2007), and new species were recently described (Trevisan \& Boldrini 2010; Lima et al. 2014; Nunes et al. 2016b). For Pará state, there is no taxonomic work focusing exclusively on the genus.

Eleocharis species are aquatic or wetland plants that grow in moist or inundated soils, lagoons, lakes, marshes, on river margins, and in the sandy coastal vegetation (known in Brazil as restinga) (Faria 1998; Gil \& Bove 2007). Abundant water and light are the main resources required for good development of the species (Gil \& Bove 2004). According to Trevisan \& Boldrini (2008), the species are ecologically important, mainly to the floristic composition and phytophysiognomy of flooded areas.

Brazil has approximately $8,500 \mathrm{~km}$ of coastline (Moraes 2007). Of this, $1,500 \mathrm{~km}$ are in the Amazon region, within the states of Amapá, Pará and Maranhão (Lacerda et al. 1984), where there is a mosaic of terrestrial and aquatic ecosystems of great environmental importance.

\footnotetext{
${ }^{1}$ Universidade Federal do Pará, Inst. Ciências Biológicas, R. Augusto Correa 1, Guamá, Belém, PA, Brazil.

${ }^{2}$ Museu Paraense Emílio Goeldi - MPEG, Campus de Pesquisa, Coord. Botânica - COBOT, Av. Perimetral 1901, Terra Firme, 66077-530, Belém, PA, Brazil.

${ }^{3}$ Museu Paraense Emílio Goeldi, Coord. Botânica, Prog. Capacitação Institucional, Av. Perimetral 1901, Terra Firme, 66077-830, Belém, Pará, Brazil.

${ }^{4}$ Author for correspondence: andregil@museu-goeldi.br
} 
Among the various environments of the coastal region of the country, the restinga occupies around $5,000 \mathrm{~km}$, which represents $79 \%$ of coastal Brazil (Lacerda et al. 1984; Araújo $\&$ Lacerda 1987). Along the Amazon coast, the restinga occurs discontinuously and occupies an estimated $1,000 \mathrm{~km}^{2}$. Pará state contains $40 \%$ of the Amazonian restinga, which occurs in a coastal plain cut by peninsulas and bays (Amaral et al. 2008; Silva et al. 2010; Schneider et al. 2017).

According to the concept presented in the Brazilian law (CONAMAn ${ }^{0}$ 303/2002 Resolution), restinga represents "sandy deposits, parallel to the coastline, produced by sedimentation processes, where different communities are found under marine influence". These communities form a vegetation complex near the ocean that is mainly influenced by the soil (Silva 1999). The restinga vegetation is responsible for assuring balance in the ecosystems, as well as harboring species of economic, medicinal, food, and ornamental importance (Santos et al. 1999).

The objective of the present study was to better understand the taxonomy of Eleocharis species that occur in the restinga of Pará state, Amazon, Brazil. An identification key, morphological descriptions, taxonomic comments and illustrations of the studied species of Eleocharis are provided.

\section{Material and Methods}

Restinga in Pará state includes six distinct plant formations: halophile, creeping psammophile, herbaceous marshes, dune fields, open shrub formations, and restinga forest (Amaral et al. 2008). In Pará state, restinga is present in the municipalities of São Caetano de Odivelas, Curuça, Marapanim, Maracanã, Salinópolis, São João de Pirabas, Quatipurú, Tracuateua, Bragança, Augusto Corrêa and Viseu (Fig. 1). The climate is hot throughout the year, with an average annual temperature of $26^{\circ} \mathrm{C}$ and minimum temperature above $18^{\circ} \mathrm{C}$ (Silva et al. 2010).

Specimens from HBRA, IAN and MG herbaria, and images of specimens online at $B, G$, INPA, NY, P, RB and UB, were analyzed based on collections from the municipalities in Pará state where restinga is found (excluding the Marajó Island municipalities). Collected material was processed and deposited in MG.
Species were determined using the literature, such as Svenson $(1929,1932,1934,1937,1939)$, Barros (1960), González-Elizondo (1994), Faria (1998), González-Elizondo \& Reznicek (1998), Gil \& Bove (2004, 2007), Nunes et al. (2016a), Simpson (2006) and Trevisan \& Boldrini (2008, 2010), including all of the original publications and types digitized and available on the Biodiversity Heritage Library $(<\mathrm{http}$ ://www.biodiversitylibrary. org/subject/Botany $>$ ), Botanicus Digital Library (<http://www.botanicus.org/>) and JSTOR Global Plants (<https://plants.jstor.org/>) sites.

The correct nomenclature of the species and their basionyms, as well as abbreviations of the original publications and authors, are based on The International Plant Names Index $(<\mathrm{http}: / /$ http://www.ipni.org/>) and Tropicos (<http:// www.tropicos.org/Home.aspx $>$ ) sites. The terminology used to describe the species follows Nunes et al. (2016b).

Geographic distribution and habitat data were taken from specimen labels, field observations and literature.

\section{Results and Discussion}

A total of 144 specimens of Eleocharis from restinga in Pará state were analyzed. Eight species were confirmed, including two that are new records for the state.

1. Eleocharis R. Br., Prodr. 1: 224. 1810. Type: Eleocharis palustris (L.) Roem. \& Schult. Syst. Veg. 2: 151. 1817. Scirpus palustris L. Sp. P1. 1: 47. 1753.

Herbs, erect, caespitose or rhizomatous. Culms cylindrical, quadrangular, or slightly to evidently trigonous in cross section, septate or not. Leaves reduced to sheaths at the base of the culm (leaf blade absent), sheaths membranaceous or coriaceous. Inflorescence a single spikelet at culm apex; involucral bracts absent. Spikelets globose, ovoid, ellipsoid or lanceoloid; sometimes dimorphic. Glumes persistent or deciduous, spiral, distichous or subdistichous; lower glumes fertile or sterile. Perianth bristles present, absent or rudimentary. Stamens 1-3. Stigma bifid or trifid. Achene biconvex or trigonous, smooth or reticulate, white to black; stylopodium confluent or not with the rest of the achene body (adapted from Svenson 1929; Gil \& Bove 2007; Trevisan 2009). 


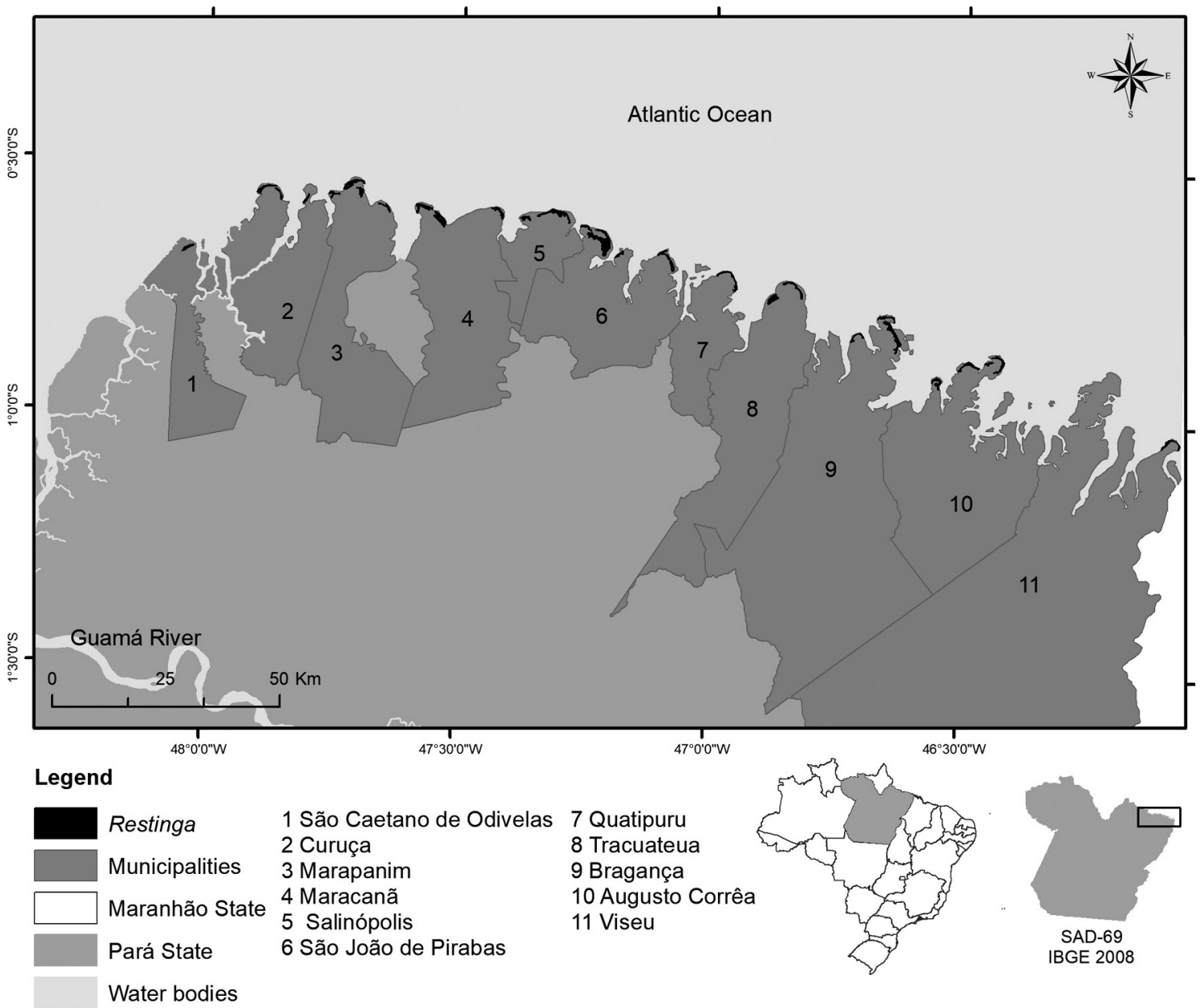

Figure 1 - Location of the study area. Adapted from IBGE (2008).

\section{Identification key to the species of Eleocharis in the restinga of Pará state}

1. Plants robust, 39-98 $\times 0.2-0.6 \mathrm{~cm}$; spikelets oblongoid or lanceoloid; glumes cartilaginous.

2. Culms solid, spongy, trigonous to obtusely trigonous in cross section; achenes with thickening at apex 1.6. Eleocharis mutata

2'. Culms hollow, septate (septa very evident), cylindrical in cross section; achenes with a constriction at apex.

3. Culms with conspicuous central vascular bundle; glumes with truncate to rounded apex ....

1.2. Eleocharis endounifascis

3'. Culms without conspicuous central vascular bundle; glumes with subacute to obtuse apex

1.4. Eleocharis interstincta

1'. Plants delicate, $1.2-38.5 \times 0.02-0.11 \mathrm{~cm}$; spikelets ovoid, ellipsoid or globose; glumes membranaceous

4. Styles bifid; achenes biconvex.

5. Sheaths without evident longitudinal ribs, apex oblique, cuspidate to apiculate, without hyaline appendix; achenes black, sometimes vinaceous

1.3. Eleocharis geniculata

5'. Sheaths with 5 evident, longitudinal ribs, apex truncate, mucronate, with hyaline, rugose appendix; achenes dark brown to dark green .... 1.7. Eleocharis sellowiana

4'. Styles trifid; achenes trigonous. 
6. Perennial herbs; culms quadrangular in cross section; glumes elliptical; lower glume continuous with the culm 1.5. Eleocharis minima

6'. Annual herbs; culms cylindrical in cross section; glumes oval-lanceolate or oblong; lower glume articulate with the culm

7. Glumes oval-lanceolate; stamens 2; achenes obovoid, longitudinaly ribbed surface; stylopodium pyramidal 1.1. Eleocharis bahiensis

7'. Glumes oblong; stamen 1; achenes urceoloid, reticulate surface; stylopodium discoid 1.8. Eleocharis urceolata

1.1. Eleocharis bahiensis D.A. Simpson, Kew Bull. 43: 127. 1988.

Fig. 2a-c

Annual herbs, caespitose, $2.7-13.2 \mathrm{~cm}$ long. Culms $2.5-12.7 \times 0.03-0.08 \mathrm{~cm}$, cylindrical in cross section, solid, spongy, conspicuous central vascular bundle absent, surface sulcate. Sheaths 0.5-3.5 $\mathrm{cm}$ long, membranaceous, without longitudinal ribs, apex acute to attenuate, aristate, with hyaline margins, apical hyaline appendix absent. Spikelets $2-5 \times 1.5-3 \mathrm{~mm}$, ovoid to ellipsoid, basal culmless spikelets absent; glumes spirally arranged, 1-1.9 $\times 1-1.5 \mathrm{~mm}$, oval-lanceolate, membranaceous, sides stramineous, sometimes vinaceous with a prominent brown keel, margins hyaline, apex emarginate; lower glume sterile, articulate with the culm. Stamens 2. Styles 3. Perianth bristles absent. Achene $0.5-0.8 \times 0.3-0.4 \mathrm{~mm}$, trigonous, obovoid, greyish white, surface longitudinaly ribbed, trabeculated between ribs, presence of a constriction between the achene body and stylopodium; stylopodium pyramidal, brown.

Selected material: Bragança, Península de Ajuruteua, 10.V.2007, fl. and fr., U. Mehlig $328 b$ (HBRA). Maracanã, Ilha de Algodoal, Praia da Princesa, 2225.V.1994, fl. and fr., M.N. Bastos et al. 1639 (MG). Marapanim, estrada sentido Praia do Crispim, próximo a placa do $\mathrm{km} \mathrm{7,} \mathrm{ao} \mathrm{lado} \mathrm{da} \mathrm{casa} \mathrm{abandonada,} \mathrm{24.VII.2015,}$ fl. and fr., J.F. Maciel-Silva et al. 3 (MG).

Distribution and habitat: Brazil (BFG 2015). This is the first record for the state of Pará. In Brazil, its also occurs in the Northeast (BA) region (BFG 2015). In the restinga of Pará state, this species is found in herbaceous marshes and dune fields. Comments: Eleocharis bahiensis is characterized mainly by its glumes with a prominent brown keel, absence of perianth bristles, achenes that are trigonous, greyish white, with a longitudinally ribbed surface and trabeculae between the ribs, and conic stylopodium. It can be confused with E. filiculmis Kunth, a species not recorded for the study area, by the emarginate glumes and trigonous achenes; however, E. bahiensis possesses a sheath with an acute to attenuate, aristate apex and hyaline margins ( $v s$. oblique to cuspidate apex and margins not hyaline), achene surface longitudinally ribbed with trabeculae between the ribs ( $v s$. achene surface slightly ribbed and no trabeculae), and absence of perianth bristles ( $v s$. perianth bristles present).

\subsection{Eleocharis endounifascis Hinchliff \& Roalson,} Phytotaxa 7: 20. $2010 . \quad$ Fig. 2d-f

Perennial herbs, caespitose, 49-94 cm long. Culms $48-90 \times 0.2-0.4 \mathrm{~cm}$, cylindrical in cross section, hollow, transversely septate, conspicuous central vascular bundle present, surface not sulcate. Sheaths $2.5-15 \mathrm{~cm}$ long, membranaceous, without longitudinal ribs, apex obtuse to apiculate, without hyaline margins, apical hyaline appendix absent. Spikelets $10-40 \times 4-5 \mathrm{~mm}$, lanceoloid, basal culmless spikelets absent; glumes spirally arranged, 4-6 $\times 2-3.8 \mathrm{~mm}$, suboboval, cartilaginous, sides stramineous without a prominent keel, margins hyaline with one submarginal dark brown to black line, apex truncate to rounded; lower glume sterile, continuous with the culm. Stamens 3 . Styles 3. Perianth bristles 7, white to stramineous, retrorsely scabrous. Achene $2-2.5 \times 1-1.1 \mathrm{~mm}$, biconvex, obovoid, light brown, surface with longitudinal rows of isodiametric cells, presence of a constriction between the achene body and stylopodium; stylopodium long-pyramidal, laterally compressed, dark brown to black.

Selected material: Maracanã, Ilha de Algodoal, encontrada em solo arenoso, próximo à curso d'água, 23.V.2008, fl. and fr., L.K.M. Rodrigues 43 (IAN, MG). Marapanim, estrada sentido Praia do Crispim, próximo a placa do $\mathrm{km} \mathrm{7}$, ao lado da casa abandonada, 24.VII.2015, fl. and fr., J.F. Maciel-Silva et al. 7 (MG). Salinópolis, Restinga da praia do Atalaia, beira de lago, 20.IX.2013, fl. and fr., A. Gil et al. 312 (MG). São João de Pirabas, Ilha de Fortaleza, 15.I.1992, fr., M.N. Bastos et al. 1203 (MG).

Distribution and habitat: Venezuela, Guyana and Brazil (Hinchliff et al. 2010). In Brazil, this species occurs in the North (PA), Northeast (CE, PE, SE), Central-West (MS) and Southeast (RJ, 

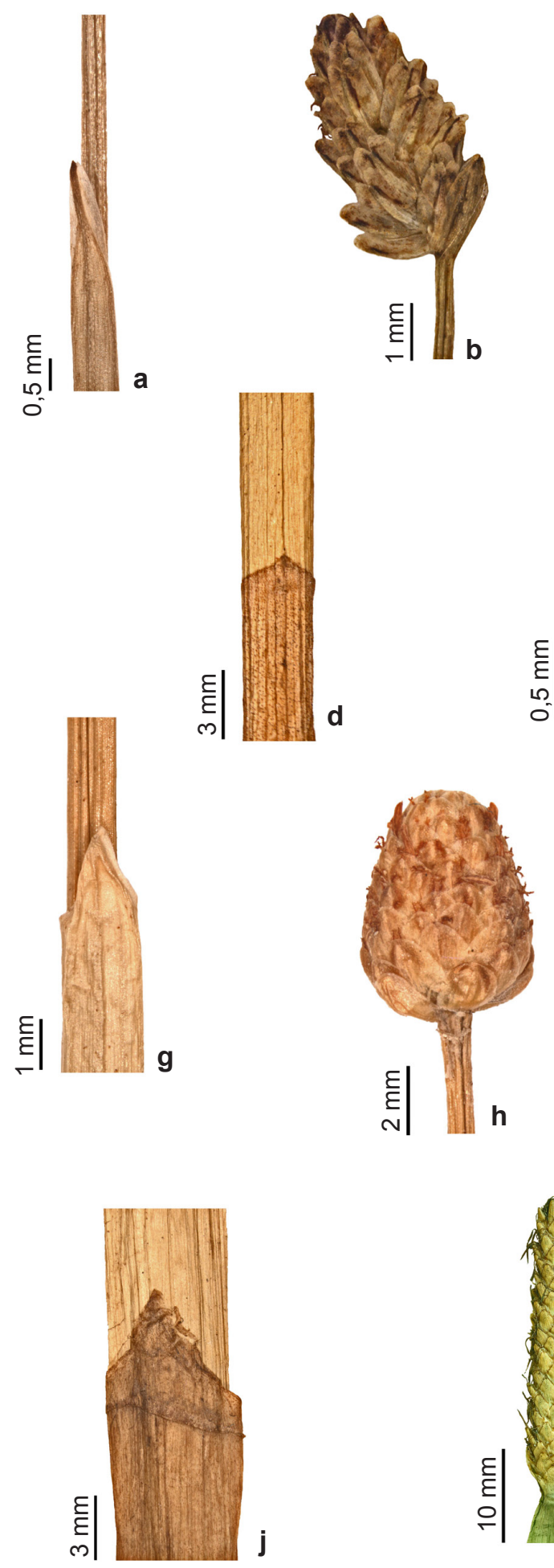
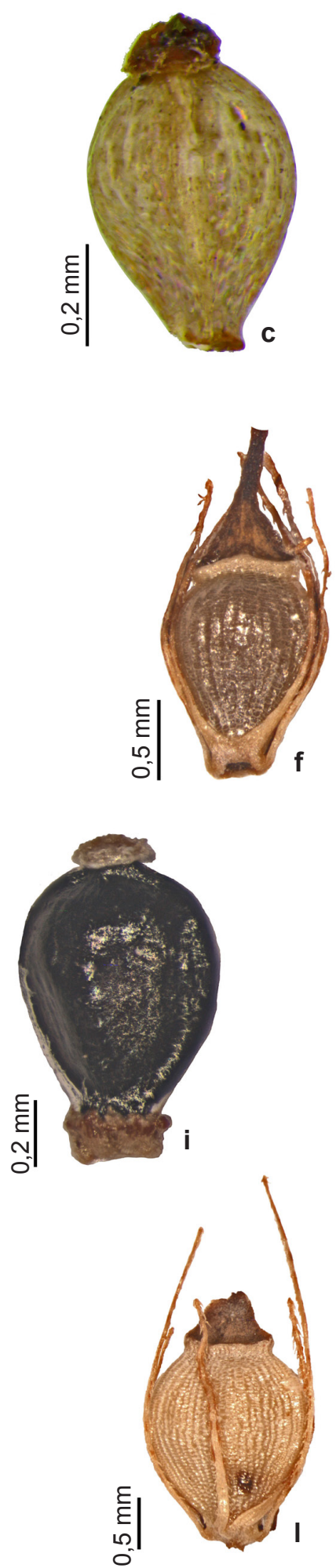

Figure 2 - a-c. Eleocharis bahiensis - a. sheath; b. spikelets; c. achene. d-f. E. endounifascis - d. sheath; e. spikelets; f. achene. g-i. E. geniculata - g. sheath; h. spikelets; i. achene. j-1. E. interstincta - j. sheath; k. spikelets; 1. achene (a-c. J.F. Maciel-Silva et al. 3; d-f. J.F. Maciel-Silva et al. 7; g-i. M.N. Bastos et al. 638; j-1. S. Almeida et al. 325). 
SP) regions (BFG 2015; Nunes et al. 2016a). In the restinga of Pará state, this species was found in herbaceous marshes, permanent lakes, and streams formed from the accumulation of rain in open shrub formations.

Comments: Eleocharis endounifascis is mainly characterized by the hollow, septate (septa evident externally) culm cylindrical in cross section, and cartilaginous glumes with a submarginal dark brown to black line. It can be confused with $E$. interstincta (Vahl) Roem. \& Schult., primarily because of the hollow culm that has externally evident septa and is cylindrical in cross section, achene surface with longitudinal rows of isodiametric cells, and longpyramidal stylopodium. However, E. endounifascis differs mainly by having a single, conspicuous central vascular bundle along the culm.

1.3. Eleocharis geniculata (L.) Roem. \& Schult., Syst. Veg. 2: 150. 1817. Scirpus geniculatus L., Sp. Pl. 1: 48. 1753.

Fig. 2g-i

Perennial herbs, caespitose, $3-38.5 \mathrm{~cm}$ long. Culms $2.7-37.5 \times 0.08-0.11 \mathrm{~cm}$, cylindrical in cross section, solid, spongy, conspicuous central vascular bundle absent, surface sulcate. Sheaths $0.5-10 \mathrm{~cm}$ long, membranaceous, without longitudinal ribs, apex oblique, cuspidate to apiculate, without hyaline margins, apical hyaline appendix absent. Spikelets 3-10 × 2.5-7.5 mm, globose to ovoid, basal culmless spikelets absent; glumes spirally arranged, $1-2.5 \times 1-1.5 \mathrm{~mm}$, globose to oval, membranaceous, sides and keel stramineous, keel not prominent, without hyaline margins, apex obtuse to rounded; lower glume sterile, articulate with culm. Stamens 2. Styles 2. Perianth bristles (5-) 7, sometimes rudimentary or absent, brown, margins retrorsely scabrous. Achene 0.9-1.1 × 0.4-0.8 mm, biconvex, obovoid, black, sometimes vinaceous, surface smooth, presence of a constriction between the achene body and stylopodium; stylopodium discoid, light brown. Selected material: Augusto Corrêa, APA do Urumajó, na Ilha de Camarão Açu, 11.XI.1999, fl. and fr., L.C.B. Lobato et al. 2546 (MG). Bragança, Península de Ajuruteua, dunas e campos noroeste Vila Bonifácio, campo $0,5 \mathrm{~km}$ oeste do $1^{\circ}$ cordão de dunas, 10.V.2007, fl. and fr., U. Mehlig 328 (HBRA, MG). Curuça, Ilha Romana, praia na Ponta da Romana no noroeste da ilha, 0³3'54"S, 47 55'00'W, 23.V.2010, fl. and fr., $U$. Mehlig et al. 795 (HBRA). Maracanã, Ilha de Algodoal, praia da Princesa, 23.X.1990, fl. and fr., M.N. Bastos et al. 638 (MG). Marapanim, Crispim, 26.IV.2008, fl. and fr., M.G.L. Wanderley et al. 2660 (MG). Salinópolis, 29.IX.1957, fl. and fr., W.A. Egler 602 (MG). São João de Pirabas, Praia do Buraco, dunas rasas e apicum próximo à beira mar, $0^{\circ} 40^{\prime} 54.2^{\prime \prime} \mathrm{S}, 47^{\circ} 06^{\prime} 47.6^{\prime \prime} \mathrm{W}$, 15.V.2011, fl. and fr., U. Mehlig et al. 996 (HBRA). Viseu, Fernandes Belo, restinga da Vila Apeu-Salvador, 0 55'00.8”S, 46 '11'38.9'W, 24.VI.2015, U. Mehlig et al. 1674 (HBRA).

Distribution and habitat: Tropics and subtropics (Gil \& Bove 2007; Trevisan \& Boldrini 2008). In Brazil occurs in all states (BFG 2015). This species of Eleocharis is the most common in the restinga of Pará state, where it is encountered in halophile and dune field environments near water courses. Comments: Eleocharis geniculata is characterized by the sheath with a cuspidate to apiculate apex, globose to ovoid spikelets, biconvex, black or sometimes vinaceous achenes with a smooth surface, discoid stylopodium, and presence or absence of perianth bristles that can exceed the achene. The great morphological variation in relation to the size of the perianth bristles, and their presence or absence, has been cited by other authors (e.g., González-Elizondo 1994; Faria 1998; Trevisan \& Boldrini 2008; Nunes et al. 2016a), and for the specimens we analyzed this character was also very variable. Eleocharis geniculata is similar to E. maculosa (Vahl) Roem. \& Schult., a species not recorded for the study area, because of the ovoid spikelets, sterile lower glume, and biconvex, obovoid, black achenes. However, E. maculosa differs mainly by its sheath with a conspicuous apical hyaline and rugose appendix.

1.4. Eleocharis interstincta (Vahl) Roem. \& Schult., Syst. Veg. 2: 149. 1817. Scirpus interstinctus Vahl, Enum. Pl. 2: 251. 1805.

Fig. $2 \mathrm{j}-1$

Perennial herbs, caespitose, $52-91 \mathrm{~cm}$ long. Culms 49.4-87.5 × 0.5-0.6 cm, cylindrical in cross section, hollow, transversely septate, conspicuous central vascular bundle absent, surface not sulcate. Sheaths 4-20 cm long, membranaceous, without longitudinal ribs, apex obtuse to acute, without hyaline margins, apical hyaline appendix absent. Spikelets 21-35 $\times 4-6 \mathrm{~mm}$, oblongoid to lanceoloid, basal culmless spikelets absent; glumes spirally arranged, 5-6 $\times 2.5-3 \mathrm{~mm}$, elliptic to oboval, cartilaginous, sides and keel stramineous, keel not prominent, margins hyaline, apex subacute to obtuse; lower glume sterile, continuous with the culm. Stamens 3. Styles (2-) 3. Perianth bristles 7, stramineous, margins retrorsely scabrous. Achene 2.4-3 × 1-2 mm, biconvex, obovoid, stramineous, surface with longitudinal rows of isodiametric cells, presence of a slight constriction between 
the achene body and stylopodium; stylopodium triangular, brown.

Examined material: Bragança, Campos graminosos inundáveis, 24.VII. 1990, fl. and fr., S. Almeida et al. 325 (MG). Quatipuru, Campo Grande, 2.IV.1963, fl., W. Rodrigues 5081 (INPA, MG, UB).

Distribution and habitat: Africa, United States, Central America and South America (Colombia, Venezuela, Guyana, Suriname, Peru, Bolivia, Paraguay and Brazil) (Gil \& Bove 2007; Trevisan $\&$ Boldrini 2008). In Brazil, this species occurs in all states (BFG 2015). In the restinga of Pará state, it is found in herbaceous marshes and inundated areas of open shrub formations.

Comments: Eleocharis interstincta is mainly characterized by the cylindrical culms with very evident septa, sheath with an acuminate apex, glumes with obtuse apex, and perianth bristles with retrorsely scabrous margins. It is similar to E. endounifascis (vide comments under $E$. endounifascis).

1.5. Eleocharis minima Kunth, Enum. Pl. 2: 139. 1837.

Fig. 3a-c

Perennial herbs, caespitose, $1.2-11 \mathrm{~cm}$ long. Culms $1-10.5 \times 0.02-0.03 \mathrm{~cm}$, quadrangular in cross section, solid, spongy, conspicuous central vascular bundle absent, surface sulcate. Sheaths $0.2-2.1 \mathrm{~cm}$ long, membranaceous, without longitudinal ribs, apex acute to obtuse, with hyaline margins, apical hyaline appendix absent. Spikelets $2.5-6 \times 1-1.8 \mathrm{~mm}$, ovoid to ellipsoid, basal culmless spikelets present; glumes distichously to spirally arranged, $1.2-2.1 \times 0.7-1$ $\mathrm{mm}$, elliptic, membranaceous, sides stramineous, keel green and prominent, with hyaline margins, apex obtuse; lower glume sterile, continuous with the culm. Stamens 2-3. Styles 3. Perianth bristles rudimentary or absent, when rudimentary, white to light brown, margins smooth. Achene $0.7-0.9 \times$ 0.3-0.5 mm, trigonous, ellipsoid to obovoid, white, yellowish to brownish, surface smooth, sometimes slightly verrucose, with evident cells, presence of a constriction between the achene body and stylopodium; stylopodium short-pyramidal, brown. Examined material: Bragança, Península de Ajuruteua, dunas e campos ao noroeste da Vila Bonifácio, 20.VIII.2006, fr., L.O. Santos 29 (HBRA). Maracanã, Ilha de Algodoal, encontrada em solo arenoso, próximo à curso d'água, 22.V.2008, fl. and fr., L.K.M. Rodrigues 25 (IAN, MG). Marapanim, Vila de Cajutuba, 22.VII.1994, fl. and fr., S.V. da Costa Neto et al. 2 (MG). São João de Pirabas, Ilha de Fortaleza, 15.I.1992, fl. and fr., M.N. Bastos et al. 1217 (MG). Viseu, Fernandes Belo, restinga da Vila Apeu-Salvador, $0^{\circ} 55^{\prime} 12.1^{\prime \prime}$ ', $46^{\circ} 11^{\prime} 25.7^{\prime \prime} \mathrm{W}$, 23.VI. 2015, fl. and fr., U. Mehlig et al. 1621 (HBRA). Distribution and habitat: United States, Central America and Brazil (Svenson 1929; Trevisan \& Boldrini 2008). In Brazil, this species occurs in all states (BFG 2015). In the restinga of Pará state, it occurs in flooded areas of dune fields and streams formed by rainfall in open shrub formations.

Comments: Eleocharis minima is mainly characterized by the capillary culm, distichously to spirally glumes with stramineous sides, prominent, green keel, lower glume continuous with the culm, perianth bristles absent or rudimentary, and trigonous, white, yellowish to brownish achene with a short-pyramidal stylopodium. It can be confused with $E$. nana Kunth, a species not recorded for the study area, mainly due to the similarity in habit, capillary culm, obtuse sheath apex, and glumes subdistichously to spirally arranged. Eleocharis minima differs from E. nana mainly by having perianth bristles rudimentary or absent, smooth when rudimentary ( $v s$. perianth bristles 5 , retrorsely scabrous). It is the species with the highest number of misidentifications, which is possibly due to the morphological complexity found in the representatives of series Tenuissimae (C.B. Clarke) Svenson (González-Elizondo \& Peterson 1997; Trevisan \& Boldrini 2010; Roalson et al. 2010). Most of the specimens had basal culmless spikelets, which characterizes the species in series Tenuissimae subser. Chaetariae (C.B. Clarke) Svenson (Svenson 1929; GonzálezElizondo \& Peterson 1997; Trevisan \& Boldrini 2010; Nunes et al. 2016b).

1.6. Eleocharis mutata (L.) Roem. \& Schult., Syst. Veg. 2: 155. 1817. Scirpus mutatus L., Syst. Nat. 2: 867.1759.

Fig. 3d-f

Perennial herbs, caespitose, 39-98 cm long. Culms $36.5-93 \times 0.2-0.55 \mathrm{~cm}$, trigonous to obtusely trigonous in cross section, solid, spongy, conspicuous central vascular bundle absent, surface not sulcate. Sheaths $3.5-36 \mathrm{~cm}$ long, membranaceous, without longitudinal ribs, apex acuminate to caudate, with hyaline margins, apical hyaline appendix absent. Spikelets 21-57 $\times$ 4-5 mm, lanceoloid, basal culmless spikelets absent; glumes spirally arranged, $3.1-4.6 \times 2.2-4.1$ $\mathrm{mm}$, oblong to obovate, cartilaginous, sides with vinaceous dots, keel stramineous, not prominent, margins hyaline, apex obtuse to rounded; lower glume sterile, continuous with culm. Stamens 3 . Styles 3. Perianth bristles 6-7, light brown, margins 

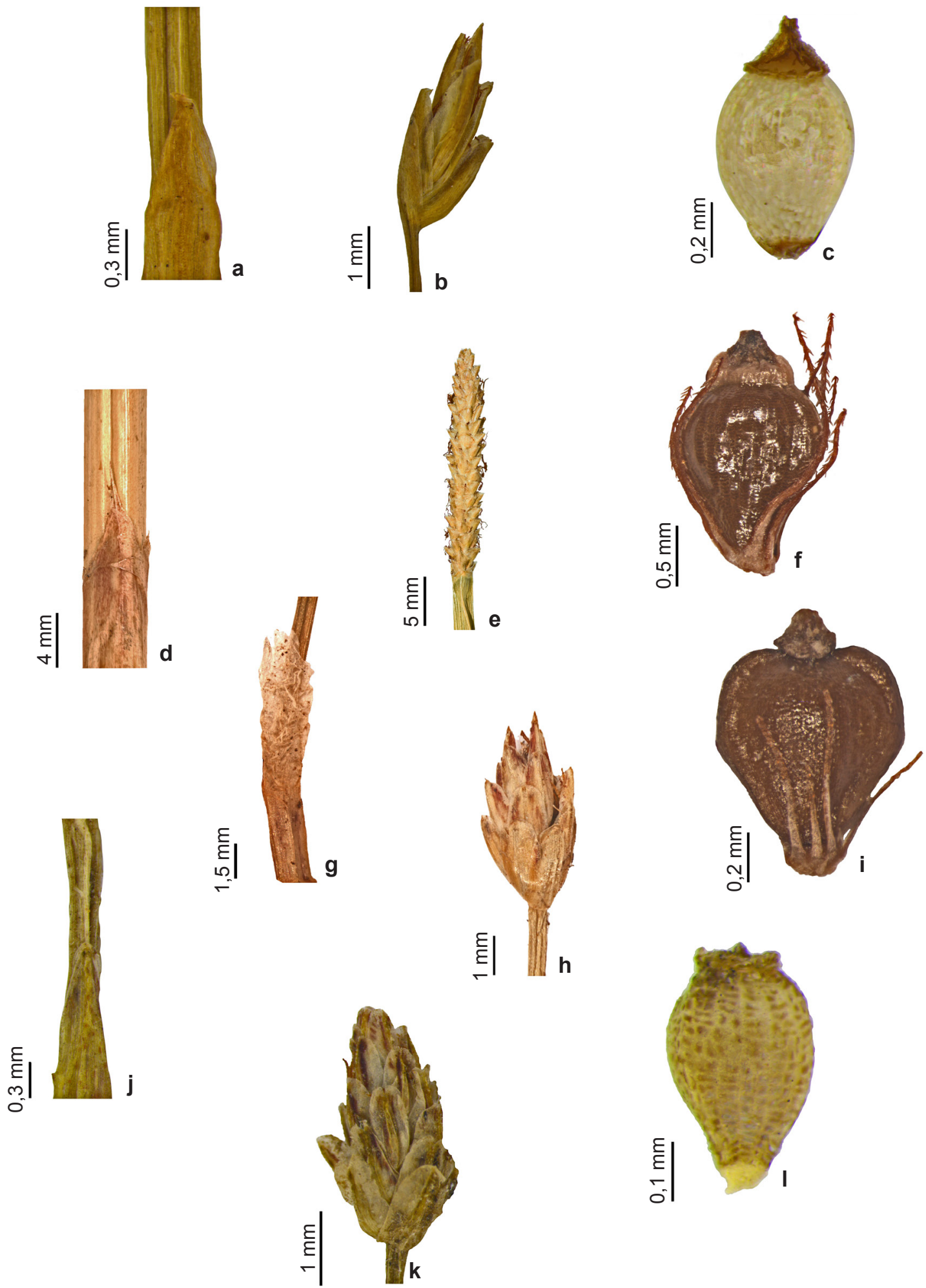

Figure 3 - a-c. Eleocharis minima - a. sheath; b. spikelets; c. achene. d-f. E. mutata - d. sheath; e. spikelets; f. achene. g-i. E. sellowiana -g. sheath; h. spikelets; i. achene. j-1. E. urceolata - j. sheath; k. spikelets; 1. achene (a-c. L.K.M. Rodrigues 25; d-f. U. Mehlig et al. 1703; g-i. M.N. Bastos et al. 1184; j-1. L.O. Santos et al. 290). 
retrorsely scabrous. Achene 2-2.1 × 1.1-1.4 mm, biconvex, obovoid, yellowish to light brown, surface with longitudinal rows of isodiametric cells, presence of an annular dilation between the achene body and stylopodium; stylopodium deltoid, brown.

Selected material: Bragança, Península de Ajuruteua, dunas e campos noroeste Vila Bonifácio, 050'10"S, 46'37'17''W, 05.VI.2007, fl. and fr., L.O. Santos et al. 349 (HBRA, MG). Maracanã, Ilha de Maiandeua, 14.VI.1994, fl., M.N. Bastos et al. 1693 (MG). Marapanim, Lesta da vila de Pescadores de Camará, ca. $11 \mathrm{~km}$ a noroeste de Marudá, $0^{\circ} 37^{\prime} \mathrm{S}, 47^{\circ} 41^{\prime} \mathrm{W}, 3-4$. IV.1980, fl., G. Davidse et al. 17839 (MG). Salinópolis, Cuiarana, Ilha de Itarana 21.IX.2013, fl. and fr., A. Gil et al. 372 (MG). São João de Pirabas, Ilha de Fortaleza, 15.I. 1992, fl., M.N. Bastos et al. 1202 (MG). Viseu, Fernandes Belo, restinga da Vila Apeu-Salvador, pequeno lago margeando cordão de dunas, $0^{\circ} 55^{\prime} 13.8$ 'S, $46^{\circ} 12$ '13.3”W, 25.VI.2015, fl. and fr., U. Mehlig et al. 1703 (HBRA).

Distribution and habitat: Africa, Oceania, Mexico, South America (Venezuela, Colombia, Guyana and Brazil) (Svenson 1929; Gil \& Bove 2007). In Brazil, this species occurs in the North (PA), Northeast (AL, BA, CE, MA, PA, PE, PI, RN, SE), Southeast (ES, RJ, SP) and South (PR, SC) regions (BFG 2015). It is among the most collected species in the restinga of Pará state, where it is found in herbaceous marshes, near streams in dune fields, and in open shrub formations.

Comments: Eleocharis mutata is mainly characterized by the culms that vary from trigonous to obtusely trigonous, membranaceous sheaths with an acuminate to caudate apex, and 6-7 perianth bristles. Most of the specimens analyzed were sterile. These were identified by comparing plants collected in nearby localities that were fertile, and characteristics of the culm, sheath, spikelets and glume were fundamental to confirm the identity of the species. Eleocharis acutangula (Roxb.) Schult., a species not recorded for the study area, is similar because of the culm trigonous in cross section, cylindrical spikelets and cartilaginous glumes, but $E$. mutata differs by having a sterile lower glume (vs. fertile) and an annular dilation between the achene body and stylopodium ( $v s$. presence of a constriction between the achene body and stylopodium).

1.7. Eleocharis sellowiana Kunth, Enum. P1. 2: 149. 1837.

Fig. 3g-i

Perennial herbs, rhizomatous, $2-25 \mathrm{~cm}$ long. Culms $1.7-24.3 \times 0.03-0.1 \mathrm{~cm}$, cylindrical in cross section, solid, spongy, conspicuous central vascular bundle absent, surface sulcate. Sheaths 0.5-2.5 cm long, membranaceous, with five, green, longitudinal ribs, apex truncate, mucronate, apical hyaline and rugose appendix present. Spikelets 3-7 × 1.4-3.5 mm, ovoid, sometimes ellipsoid, basal culmless spikelets absent; glumes spirally arranged, 1.4-2.5 × 1-1.3 mm, oblong to elliptic, membranaceous to nearly membranaceous, sides vinaceous with prominent greenish keel, margins hyaline, apex obtuse to rounded; lower glume sterile, articulate with culm. Stamens 2. Styles 2. Perianth bristles 7 , brown to vinaceous, margins retrorsely scabrous. Achene $1-1.1 \times 0.4-0.8$ $\mathrm{mm}$, biconvex, widely ellipsoid to obovoid, dark brown to dark green, surface smooth to reticulate, presence of a slight constriction between the achene body and stylopodium; stylopodium conic, light to dark brown.

Examined material: Bragança, Península de Ajuruteua, dunas e campos noroeste Vila Bonifácio, campo oeste da porção central do $3^{\circ}$ cordão de dunas, $0^{\circ} 50$ '16"S 46³7'06”W, 5.VI.2007, fl. and fr., L.O. Santos et al. 332 (HBRA, MG). Maracanã, Ilha de Algodoal, 24.V.2008, fl. and fr., L.K.M. Rodrigues 49 (MG). Marapanim, Vila de Marudá, praia do Crispim, 16.VI.1991, fl. and fr., M.N. Bastos et al. 1103 (MG). São João de Pirabas, Ilha da Fortaleza, 15.I.1992, fl. and fr., M.N. Bastos et al. 1184 (MG). Viseu, Fernandes Belo, restinga da Vila ApeuSalvador, 0`55'28.3'S, 46¹1'07.7'W, 24.VI.2015, fl. and fr., U. Mehlig et al. 1664 (HBRA).

Distribution and habitat: Mexico to South America (Colombia, Venezuela, Guyana, Ecuador, Bolivia, Paraguay, Argentina, Uruguay and Brazil) (Gil \& Bove 2007). In Brazil, this species occurs in all states (BFG 2015). In the restinga of Pará state, it occurs in flooded areas, in dune fields and open shrub formations.

Comments: Eleocharis sellowiana is mainly characterized by the sheath with five, green, evident longitudinal ribs, a mucronate apex with apical hyaline and rugose appendix, ovoid, sometimes ellipsoid spikelets, and dark green to dark brown achenes. It can be confused with Eleocharis flavescens (Poir.) Urb., a species not recorded for the study area, because of the mucronate apex of the sheath, with a rugose, hyaline appendix, and sheath with five, green, evident ribs. Gil \& Bove (2007) and Trevisan \& Boldrini (2008) highlight the differences between the stylopodium of these species, which is laterally compressed in E. sellowiana and horizontally compressed (discoid) in E.flavescens; however, in the material examined both shapes were observed on the same 
specimen. In addition to the stylopodium, there is also variation in the size of the fruit. Despite the evident variation, the specimens analyzed were closer to the circumscription of E. sellowiana and were determined as this species.

1.8. Eleocharis urceolata (Liebm.) Svenson, Rhodora 39: 219. 1937. Chaetocyperus urceolatus Liebm., Mexic. Halvgr. 243. $1850 . \quad$ Fig. 3j-1

Annual herbs, caespitose, 2-8.5 cm long. Culms 1.8-8.1 $\times$ 0.03-0.04 cm, cylindrical in cross section, solid, spongy, conspicuous central vascular bundle absent, surface sulcate. Sheaths $0.5-1 \mathrm{~cm}$ long, membranaceous, without longitudinal ribs, apex acute, margins hyaline, apical hyaline appendix absent. Spikelets $2.5-4 \times$ 1-2 mm, ovoid, basal culmless spikelets present; glumes spirally arranged, ca. $1 \times 0.5 \mathrm{~mm}$, oblong, membranaceous, sides vinaceous with prominent greenish keel, margins hyaline, apex obtuse, sometimes emarginate; lower glume fertile, articulate with the culm. Stamen 1. Styles 3. Perianth bristles absent. Achene 0.4-0.6 × 0.3-0.4 $\mathrm{mm}$, trigonous, urceoloid, white-greyish, surface reticulate, presence of a constriction between the achene body and stylopodium; stylopodium discoid, light brown.

Examined material: Bragança, Península de Ajuruteua, Salinas dos Roques (Jabuti), campo próximo à borda sul do bosque na $4^{\mathrm{a}}$ ilha de terra firme, 13.V.2007, fl. and fr., L.O. Santos et al. 290 (HBRA, MG).

Distribution and habitat: Mexico, Nicaragua and Brazil (Svenson 1929; González-Elizondo 1994; BFG 2015). This is the first record of this species for the state of Pará. In Brazil, its also occurs in the Central-West (DF) and Southeast (SP) regions (BFG 2015). In the restinga of Pará state, it is found in flooded areas of open shrub formations.

Comments: Eleocharis urceolata is characterized by the sheath with an acute apex, glumes with vinaceous sides, with prominent greenish keel, margins hyaline, and urceoloid achene with reticulate surface and discoid stylopodium. It resembles $E$. bahiensis because of the trigonous achenes and glumes articulate with the culm; however, E. urceolata differs from E. bahiensis by the sheath with an acute apex (vs. aristate), oblong glumes (vs. oval-lanceolate) and urceoloid achenes (vs. obovoid).

\section{Acknowledgements}

We thank CNPq for awarding the "Iniciação Científica" fellowship to the first author
(148620/2016-7) and the "Programa de Capacitação Institucional" (MPEG/MCTI) fellowship to the second author, and the curators of the herbaria $\mathrm{B}$, G, HBRA, IAN, INPA, MG, NY, P, RB and UB who kindly received us and/or made their archive data available. The authors also thank Nathan Smith and Daniela Zappi for the English revision. We are grateful to Milena Andrade for the confection of the map and Marco Aurélio Gomes for helping produce the illustrations.

\section{References}

Amaral DD, Prost MT, Bastos MNC, Costa Neto SV \& Santos JUM (2008) Restingas do litoral amazônico, estados do Pará e Amapá, Brasil. Boletim do Museu Paraense Emílio Goeldi 3: 35-67.

Araújo DSD \& Lacerda LD (1987) A natureza das restingas. Ciência Hoje 6: 42-48.

Barros M (1960) Las Ciperáceas del estado de Santa Catarina. Sellowia 12: 1-430.

BFG (2015) Growing knowledge: an overview of Seed Plant diversity in Brazil. Rodriguésia 66: 1085-1113.

Faria AD (1998) O gênero Eleocharis R. Br. (Cyperaceae) no estado de São Paulo. Dissertação de Mestrado. Universidade Estadual de Campinas, Campinas. 150p.

Gil ASB \& Bove CP (2004) O gênero Eleocharis R. Br. (Cyperaceae) nos ecossistemas aquáticos temporários da planície costeira do estado do Rio de Janeiro. Arquivos do Museu Nacional 62: 131-150.

Gil ASB \& Bove CP (2007) Eleocharis R. Br. (Cyperaceae) no estado do Rio de Janeiro, Brasil. Biota Neotropica 7: 163-193.

Goetghebeur P (1998) Cyperaceae. In: Kubitzki K (ed.) The families and genera of vascular plants. Vol. 4. Springer Verlag, Berlin. Pp. 141-190.

González-Elizondo MS (1994) Eleocharis. In: Flora Mesoamericana 6. Davidse G, Sousa M \& Chater AO (eds.) Universidad Nacional Autónoma de México, Cidade do México. Pp. 458-464.

González-Elizondo MS \& Peterson PM (1997) A classification of and key to the supraspecific taxa in Eleocharis (Cyperaceae). Taxon 46: 433-449.

González-Elizondo MS \& Reznicek AA (1998) Eleocharis. In: Steyermark JA, Berry PE \& Holst BK (eds.) Flora of the Venezuelan Guayana. Caesalpinaceae-Ericaceae. Vol. 4. Missouri Botanical Garden Press, Saint Louis. Pp. 548-561.

González-Elizondo MS \& Tena-Flores JA (2000) Eleocharis (Cyperaceae) in the New World. In: Wilson KL \& Morrison DA (eds.) Monocots: systematics and evolution. CSIRO Publishing, Melbourne. Pp. 637-643. 
Hinchliff EC \& Roalson EH (2009) Stem architecture in Eleocharis subgenus Limnochloa (Cyperaceae): Evidence of dynamic morphological evolution in a group of pantropical sedges. American Journal of Botany 96: 1487-1499.

Hinchliff EC, Petersen S \& Roalson EH (2010) Eleocharis endounifascis: a new species of Eleocharis subgenus Limnochloa (Cyperaceae) from northern South America. Phytotaxa 7: 19-24.

IBGE (2008) Mapa de vegetação da Amazônia Legal. Available at <http://downloads.ibge.gov.br/ downloads_geociencias.htm $>$. Access on 1 January 2017.

Lacerda LD, Araújo DSD, Cerqueira R \& Turcq B (1984) Restingas: Origem, estrutura, processos. CEUFF, Niterói. $1525 \mathrm{p}$.

Lima T, Gil ASB \& Trevisan R (2014) Eleocharis pseudobulbosa, a new species of Cyperaceae from Southern Brazil (Capão Bonito, São Paulo). Phytotaxa 116: 293-296.

Moraes CAR (2007) Contribuição para a gestão da zona costeira do Brasil: elementos para uma geografia do litoral brasileiro. Annablume, São Paulo. 232p.

Nunes CS, Bastos MNC \& Gil ASB (2016a). Flora das cangas da Serra dos Carajás, Pará, Brasil: Cyperaceae. Rodriguésia 67: 1329-1366.

Nunes CS, Trevisan R \& Gil ASB (2016b) Eleocharis pedrovianae, a new species of Cyperaceae from Northern Brazil (Serra dos Carajás, Pará state). Phytotaxa 265: 85-91.

Roalson EH, Hinchliff CE, Trevisan R \& Silva CRM (2010) Phylogenetic relationships in Eleocharis (Cyperaceae): C4 photosynthesis origins and patterns of diversification in the spikerushes. Systematic Botany 35: 257-271.

Santos JUM, Gorayeb IS \& Bastos MNC (1999) Diagnóstico para a avaliação e ações prioritárias para conservação da biodiversidade da zona costeira e marinha amazônica. Available at <http://www. anp.gov.br/brnd/round6/guias/PERFURACAO/ PERFURACAO_R6/refere/RegiaoNorte.pdf >. Access on 1 May 2016.
Schneider LJC, Bastos MNC, Costa-Neto SV \& Gil ASB (2017) Sinopse do gênero Rhynchospora (Cyperaceae) nas restingas do estado do Pará, Brasil. Rodriguésia 68: 653-670.

Silva MS, Mehlig U, Santos JUM \& Menezes MPM (2010) The coastal restinga vegetation of Pará, Brazilian Amazon: a synthesis. Revista Brasileira de Botânica 33: 563-573.

Silva SM (1999) Diagnóstico das restingas no Brasil. In: Fundação BIO RIO, Workshop Avaliação e ações prioritárias para a conservação da biodiversidade na Zona Costeira e Marinha. Porto Seguro, Anais Eletrônicos. Available at <http://www.bdt.org.br/ workshop/costa/Restinga>. Access on 1 May 2016.

Simpson AD (2006) A flora da Reserva Ducke, Amazonas, Brasil: Cyperaceae. Rodriguésia 57: 171-188.

Svenson HK (1929) Monographic studies in the genus Eleocharis. Rhodora 31: 57-242.

Svenson HK (1932) Monographic studies in the genus Eleocharis. Rhodora 34: 193-227.

Svenson HK (1934) Monographic studies in the genus Eleocharis. Rhodora 36: 377-389.

Svenson HK (1937) Monographic studies in the genus Eleocharis. Rhodora 39: 210-274.

Svenson HK (1939) Monographic studies in the genus Eleocharis. Rhodora 41: 1-110.

Trevisan R (2005) O gênero Eleocharis R. Br. (Cyperaceae - Eleocharidae) no Rio Grande do Sul. Dissertação de Mestrado. Universidade Federal do Rio Grande do Sul, Porto Alegre. 105p.

Trevisan R (2009) Eleocharis (Cyperaceae) na Região Sul do Brasil. Tese de Doutorado. Universidade Federal do Rio Grande do Sul, Porto Alegre. 225p.

Trevisan R \& Boldrini II (2008) O gênero Eleocharis R. Br. (Cyperaceae) no Rio Grande do Sul, Brasil. Revista Brasileira de Biociências 6: 7-67.

Trevisan R \& Boldrini II (2010) Novelties in Eleocharis ser. Tenuissimae (Cyperaceae), and a key to the species of the series occurring in Brazil. Systematic Botany 35: 504-511. 


\section{List of exsiccatae}

Almeida S 325 (1.4), 326 (1.6). Bastos MN 552 (1.6), 638 (1.3), 648 (1.3), 777 (1.1), 800 (1.3), 926 (1.3), 976 (1.2), 1103 (1.7), 1128 (1.3), 1184 (1.7), 1202 (1.6), 1203 (1.2), 1217 (1.5), 1597 (1.3), 1637 (1.5), 1639 (1.1), 1693 (1.6), 1799 (1.3). Calvacante P 450 (1.3), 950 (1.6). Carreira L 1448 (1.3). Costa Neto SV 2 (1.5), 20 (1.3). Davidse G 17839 (1.6). Egler WA 602 (1.3). Gil A 289 (1.3), 312 (1.2), 372 (1.6). Gurgel ESC 828 (1.3). Jangoux J 1202 (1.7). Lins A 908 (1.3), 909 (1.3). Lobato LCB 176 (1.6), 198 (1.3), 226 (1.6), 2546 (1.3). Maciel-Silva JF 3 (1.1), 4 (1.1), 5 (1.2), 6 (1.2), 7 (1.2), 8 (1.2). Mehlig U 18 (1.3), 24 (1.3), 70 (1.6), 78 (1.3), 206 (1.3), 328a (1.3), 328b (1.1), 336 (1.6), 342 (1.7), 361 (1.7), 365 (1.7), 366 (1.3), 510 (1.3), 795 (1.3), $996(1.3), 1621$ (1.5), $1636(1.7), 1664$ (1.7), 1674 (1.3), 1703 (1.6), 1707 (1.7). Menezes MPM 70 (1.3). Nascimento RESA 259 (1.6), 260 (1.3). Oliveira ES 144 (1.3), 170 (1.3), 174 (1.3). Oliveira J 954 (1.3). Oliveira L 261 (1.3), 368 (1.3), 513 (1.3). Rocha AES 279 (1.3), 308 (1.3), 831 (1.3). Rodrigues LKM 1 (1.6), 10 (1.6), 16 (1.3), 18 (1.3), 23 (1.3), 25 (1.5), 30 (1.3), 37 (1.7), 41 (1.3), 42 (1.3), 43 (1.2), 49 (1.7), 51 (1.3), 55 (1.6), 58 (1.6), 63 (1.3), 72 (1.6). Rodrigues W 5081 (1.4). Rosa WO 41 (1.3). Santos CCL 28 (1.6). Santos JUM 6B (1.3). Santos LO 29 (1.5), 290 (1.8), 332 (1.7), 347 (1.3), 349 (1.6), 392 (1.3). Silva MJ 220 (1.3). Silva RM 61 (1.3). Wanderley MGL 2660 (1.3), 2668 (1.6). 